\title{
First in situ estimations of small phytoplankton carbon and nitrogen uptake rates in the Kara, Laptev, and East Siberian seas
}

\author{
P. Sadanandan Bhavya ${ }^{1}$, Jang Han Lee ${ }^{1}$, Ho Won Lee ${ }^{1}$, Jae Joong Kang ${ }^{1}$, Jae Hyung Lee ${ }^{1}$, Dabin Lee ${ }^{1}$, So Hyun An ${ }^{1}$, \\ Dean A. Stockwell ${ }^{2}$, Terry E. Whitledge ${ }^{2}$, and Sang Heon Lee ${ }^{1}$ \\ ${ }^{1}$ Department of Oceanography, Pusan National University, Busan 609-735, Korea \\ ${ }^{2}$ Institute of Marine Science, University of Alaska, Fairbanks, AK 99775, USA
}

Correspondence: Sang Heon Lee (sanglee@ pusan.ac.kr)

Received: 8 February 2018 - Discussion started: 12 February 2018

Revised: 23 August 2018 - Accepted: 26 August 2018 - Published: 17 September 2018

\begin{abstract}
Carbon and nitrogen uptake rates by small phytoplankton $(0.7-5 \mu \mathrm{m})$ in the Kara, Laptev, and East Siberian seas in the Arctic Ocean were quantified using in situ isotope labeling experiments; this research, which was novel and part of the NABOS (Nansen and Amundsen Basins Observational System) program, took place from 21 August to 22 September 2013. The depth-integrated carbon (C), nitrate $\left(\mathrm{NO}_{3}^{-}\right)$, and ammonium $\left(\mathrm{NH}_{4}^{+}\right)$uptake rates by small phytoplankton ranged from 0.54 to $15.96 \mathrm{mg} \mathrm{C} \mathrm{m}^{-2} \mathrm{~h}^{-1}, 0.05$ to $1.02 \mathrm{mg} \mathrm{C} \mathrm{m}^{-2} \mathrm{~h}^{-1}$, and 0.11 to $3.73 \mathrm{mg} \mathrm{N} \mathrm{m}^{-2} \mathrm{~h}^{-1}$, respectively. The contributions of small phytoplankton towards the total $\mathrm{C}, \mathrm{NO}_{3}^{-}$, and $\mathrm{NH}_{4}^{+}$varied from $25 \%$ to $89 \%, 31 \%$ to $89 \%$, and $28 \%$ to $91 \%$, respectively. The turnover times for $\mathrm{NO}_{3}^{-}$and $\mathrm{NH}_{4}^{+}$by small phytoplankton found in the present study indicate the longer residence times (years) of the nutrients in the deeper waters, particularly for $\mathrm{NO}_{3}^{-}$. Additionally, the relatively higher $\mathrm{C}$ and $\mathrm{N}$ uptake rates by small phytoplankton obtained in the present study from locations with less sea ice concentration indicate the possibility that small phytoplankton thrive under the retreat of sea ice as a result of warming conditions. The high contributions of small phytoplankton to the total $\mathrm{C}$ and $\mathrm{N}$ uptake rates suggest the capability of small autotrophs to withstand the adverse hydrographic conditions introduced by climate change.
\end{abstract}

\section{Introduction}

The Arctic Ocean has always been a key attraction for oceanic expeditions due to its rapid response to changing environmental conditions caused by both natural and anthro- pogenic factors. It has been reported that the rate of decrease in the sea ice extent in the Arctic Ocean is significantly high and has gradually caused a decline in sea ice thickness over recent decades (Stroeve et al., 2008; Comiso et al., 2008; Kwok et al., 2009; Overland and Wang, 2013). As an immediate effect, sea ice retreat could benefit the primary production by autotrophs due to increased exposure to sunlight (Hill and Cota, 2005; Bélanger et al., 2008; Gradinger, 2009; Arrigo et al., 2012; Arrigo and van Dijken, 2015; Kahru et al., 2016). It was also reported that primary production in the Barents Sea increased by $30 \%$ during the warm period (i.e., 1989-1995) compared to the cold period during the 1960s (Arrigo et al., 2008; Wassmann et al., 2011). However, as a result of sea ice melting, the ice-algal communities may be replaced by pelagic communities. Although ice-algal communities are not a large contributor to primary production, their absence could potentially alter the vertical flux of organic carbon and coupling between the euphotic and benthic zones (Walsh, 1989).

Sea surface warming can also result in strong water column stratification, which can reduce the nutrient supply to the surface water and consequently cause a decrease in primary production (Bopp et al., 2001; Li et al., 2009; Tremblay and Gagnon, 2009; Martin et al., 2010; Steinacher et al., 2010; McLaughlin et al., 2010; Slagstad et al., 2011; Lee et al., 2007, 2012; Thomas et al., 2012); these conditions would cause alterations in the $\mathrm{C}$ dynamics in the Arctic Ocean (Arrigo et al., 2008; Bates and Mathis, 2009; Cai et al., 2010). How phytoplankton communities in the Arctic Ocean would respond to the physical, chemical, and biological stress introduced by global warming has been a heav- 
ily debated topic. One group of researchers has reported that there has been an enhancement in annual primary production due to increased light availability and warmer temperature in the Arctic Ocean (Arrigo et al., 2008; Arrigo and Dijken, 2011; Thomas et al., 2012). However, another group has suggested that excess moisture fluxes under warmer sea conditions can introduce wider cloud cover conditions during summer and early fall, and thus the possibility of reducing autotrophic primary production is inevitable (Eastman and Warren, 2010; Vavrus et al., 2012; Bélanger et al., 2013). Water column stratification is also a contrary effect introduced by global warming, and stratification can significantly reduce the amount of vertical mixing of nutrient-rich deep waters, lowering primary productivity (Tremblay and Gagnon, 2009; Lee et al., 2007, 2012; Yun et al., 2015). On the other hand, a decline in the nutrient concentrations in surface waters and sustained nutrient levels in the deeper waters could be an immediate effect of global warming (Vancoppenolle et al., 2013). Such an environment would be adverse for large phytoplankton communities who require more nutrients to achieve a given potential primary production level (Li et al., 2009). However, small phytoplankton (size range: $0.7-5 \mu \mathrm{m}$ ), which have lower nutrient requirements, proliferate under such conditions (Daufresne et al., 2009; Li et al., 2009). Hence, understanding the mechanism and processes of small phytoplankton metabolic activities under various environmental conditions would be a crucial aspect of Arctic Ocean ecosystem research.

A few studies have been conducted to understand the fate of small phytoplankton under changing environmental scenarios (Li et al., 2009; Yun et al., 2015). These studies have identified that the smallest phytoplankton cells can flourish under such nutrient-replete conditions; however, the larger cells decline in number ( $\mathrm{Li}$ et al., 2009). Hence, the reduction in the community average body size of the autotrophs is expected to be an obvious response to global warming (Daufresne et al., 2009). Consequently, the primary production contribution by small phytoplankton would be a substantial part of the Arctic Ocean biogeochemistry. However, the contribution of small phytoplankton to autotrophic $\mathrm{C}$ and dissolved inorganic nitrogen (here $\mathrm{DIN}=\mathrm{NO}_{3}^{-}+\mathrm{NH}_{4}^{+}$) fixation has been one of the least investigated topics in global oceanic research, particularly in the Arctic Ocean (Semiletov et al., 2005; Arrigo and van Dijken, 2011; Lee et al., 2007, 2012; Yun et al., 2012, 2015; Hill et al., 2017).

Apart from global warming, localized influences are also an important factor in controlling primary production in the Arctic Ocean. It has been reported that Arctic Ocean biogeochemistry is mainly governed by the high riverine inputs and intrusions of Atlantic and Pacific waters (Shiklomanov et al., 2000; Carmack and Macdonald, 2002; Peterson et al., 2002; Anderson et al., 2004). The major rivers that flow into the Arctic Ocean are the Ob', Lena, Yenisey, and Mackenzie rivers, and numerous smaller rivers flow in both the Amerasian and Eurasian sectors. It has been reported that the
$\mathrm{Ob}^{\prime}$ and Yenisey rivers have increased in their freshwater discharge since the 1980s (Semiletov et al., 2005; Anderson et al., 2009). These seas are situated along the continental shelf of the Arctic Ocean, which is known to be the widest and shallowest shelf in the world's oceans (Semiletov et al., 2005). These seas are characterized by highly dynamic organic matter production and export to the deeper ocean as well as profound atmospheric exchanges of volatile gases (Semiletov et al., 2005; Anderson et al., 2009).

A few studies have estimated the influence of river effluences on the C and DIN uptake rates (Lee et al., 2007, 2012; Yun et al., 2015). However, the potential impact of riverine influx on small phytoplankton uptake rates, which is relevant for the accountability of natural and anthropogenic influences on Arctic primary production, has not been investigated thus far. The present study reports the first investigation results on small phytoplankton (size: $0.7-5 \mu \mathrm{m}$ ) contributions to the $\mathrm{C}, \mathrm{NO}_{3}^{-}$, and $\mathrm{NH}_{4}^{+}$uptake rates in the Kara, Laptev, and East Siberian seas. Considering the global relevance of Arctic Ocean biogeochemistry, the present study aimed to (1) estimate the contribution of small phytoplankton to total primary production as well as the $\mathrm{NO}_{3}^{-}$and $\mathrm{NH}_{4}^{+}$uptake rates and (2) investigate various factors influencing small phytoplankton community efficiency in the Kara, Laptev, and East Siberian seas.

\section{Materials and methods}

\subsection{Study area}

The investigations on biochemical parameters and C and DIN transformation rates in the Kara, Laptev, and East Siberian seas were conducted at 19 monitoring stations selected from a total of 116 NABOS stations (Fig. 1, Table 1). The geographical boundaries of each sea were defined as per the classification performed by Pabi et al. (2008) (Fig. 1). Based on this classification, there were 4,13 , and 2 stations located in the Kara, Laptev, and East Siberian seas, respectively. The Kara and East Siberian seas have surface areas almost 2 times $\left(926 \times 10^{3} \mathrm{~km}^{2}\right.$ and $987 \times 10^{3} \mathrm{~km}^{2}$, respectively) larger than that of the Laptev Sea $\left(498 \times 10^{3} \mathrm{~km}^{2}\right)$ (Jakobsson and IBCAO Editorial Board Members, 2001). Additionally, the Laptev and East Siberian seas hold the shallowest zones of the Arctic Ocean basin, with a mean depth of $48 \mathrm{~m}$, while the Kara Sea has a mean depth of $131 \mathrm{~m}$ (Jakobsson and IBCAO Editorial Board Members, 2001).

\subsection{Sampling}

The sampling was conducted from 21 August to 22 September 2013 onboard Russian vessel Akademik Fedorov. The temperature and salinity were measured using a Seabird SBE9 plus CTD (conductivity-temperature-depth tool) equipped with dual temperature (SBE3) and conductivity (SBE4) sensors. Samples for major inorganic nutrients (i.e., 


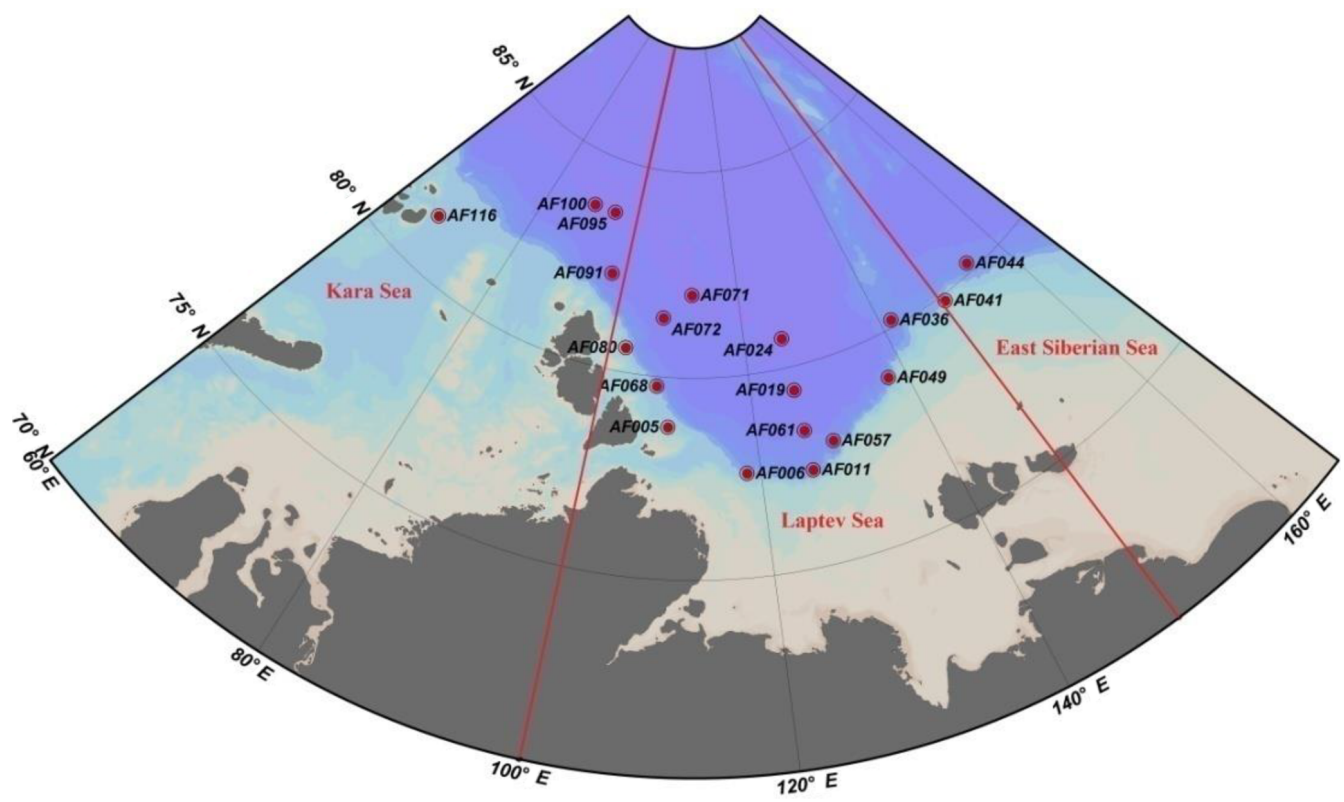

Figure 1. Sampling locations in the Kara, Laptev, and East Siberian seas in the Arctic Ocean. The red straight lines indicate the geographic boundaries used to define the seas as per Pabi et al. (2008).

$\mathrm{NO}_{3}^{-}$, nitrite $\left(\mathrm{NO}_{2}^{-}\right), \mathrm{NH}_{4}^{+}$, phosphate $(\mathrm{P})$, and silicate $\left.(\mathrm{Si})\right)$ were collected using Niskin bottles attached to the CTD device, and analysis was performed onboard using an Alpkem Model 300 Rapid Flow Nutrient Analyzer (five channels) based on Whitledge et al. (1981). The chlorophyll $a(\mathrm{Chl} a)$ samples for the small phytoplankton fraction were obtained from three light depths $(100 \%, 30 \%$, and $1 \%)$. The preparation of Chl $a$ samples was based on the standard procedure reported in previous studies on the Arctic Ocean (Lee and Whitledge, 2005; Lee et al., 2012). Water samples for small Chl $a$ fractions were sequentially filtered through a $5 \mu \mathrm{m} \mathrm{Nu}-$ cleopore and then $0.7 \mu \mathrm{m}$ pore-sized Whatman GF/F filters $(47 \mathrm{~mm})$. Furthermore, the GF/F filters were wrapped in aluminum foil and kept frozen at $-80^{\circ} \mathrm{C}$ until analysis. During the analysis, the $\mathrm{Chl} a$ fractions from the filters were extracted using $90 \%$ acetone treatment at $5{ }^{\circ} \mathrm{C}$ for $24 \mathrm{~h}$. The extracted Chl $a$ samples were subjected to spectrophotometric analysis onboard using a pre-calibrated Turner Designs model $10 \mathrm{AU}$ fluorometer. Samples for the C and DIN uptake rates were collected from six in situ light level depths $(100 \%, 50 \%, 30 \%, 12 \%, 5 \%$, and $1 \%)$ determined at each station based on the euphotic depth, which is based on the Lambert-Beer law. Underwater PAR sensors (and/or optical instruments) could not be used due to logistical problems, and the euphotic depth was calculated using the Secchi depth, which is a widely used method (Son et al., 2005; Tremblay et al., 2000; Lee et al., 2012, 2017a, b; Bhavya et al., 2016, 2017).

\section{$2.3{ }^{13} \mathrm{C}$ and ${ }^{15} \mathrm{~N}$ labeling experiments}

The estimation of the $\mathrm{C}$ and DIN uptake rates was performed using ${ }^{13} \mathrm{C}$ and ${ }^{15} \mathrm{~N}$ duel isotope labeling experiments (Dugdale and Goering, 1967; Slawyk et al., 1977; Dugdale and Wilkerson, 1986). Seawater samples at each light depth were collected using Niskin bottles attached to the CTD Rosette and transferred to acid-cleaned polycarbonate incubation bottles (approximately 1L) wrapped with neutral density light filters (LEE filters) to match the desired light levels. Immediately, samples were spiked with $98 \%-99 \%$ enriched tracer solutions of $\mathrm{NaH}^{13} \mathrm{CO}_{3}, \mathrm{~K}^{15} \mathrm{NO}_{3}$, or ${ }^{15} \mathrm{NH}_{4} \mathrm{Cl}$ at concentrations of $\sim 0.3 \mathrm{mM}, \sim 0.8 \mu \mathrm{M}$, and $\sim 0.1 \mu \mathrm{M}$ for the estimations of the $\mathrm{C}, \mathrm{NO}_{3}^{-}$, and $\mathrm{NH}_{4}^{+}$uptake rates, respectively. Furthermore, the samples were subjected to 4 $6 \mathrm{~h}$ of incubation in large transparent Plexiglas incubators on deck under natural light conditions, and these incubators were provided with running surface seawater. Immediately after the incubation, $0.3 \mathrm{~L}$ of incubated samples were filtered through pre-combusted GF/F filters ( $25 \mathrm{~mm}$ diameter) for the total uptake rate estimation. The samples for the small fraction and sub-samples $(0.5 \mathrm{~L})$ of the incubated waters were passed through $5 \mu \mathrm{m}$ Nuclepore filters $(47 \mathrm{~mm})$ to remove large phytoplankton cells $(>5 \mu \mathrm{m})$, and then the filtrate was passed through pre-combusted GF/F $(25 \mathrm{~mm})$ for the small phytoplankton (Lee et al., 2013). The values for large phytoplankton in this study were obtained from the difference between the small and total fractions (Lee et al., 2013). Samples were kept frozen $\left(-20^{\circ} \mathrm{C}\right)$ until the mass spectrometric analysis (Finnigan Delta $+\mathrm{XL}$ ) at the stable isotope laboratory of the University of Alaska Fairbanks, USA. The uncer- 
Table 1. The physical and chemical properties of the sampling locations in the East Siberian Sea and the Laptev Sea, where station depth, euphotic depth, sea surface temperature (SST), and sea ice cover (SIC) are represented in $\mathrm{m}, \mathrm{m},{ }^{\circ} \mathrm{C}$, and $\%$, respectively. The sea surface salinity (SSS) is represented in practical salinity unit (PSU). The nutrient concentrations $\left(\mathrm{NO}_{2}^{-}+\mathrm{NO}_{3}^{-}\right.$, phosphate $(\mathrm{P})$, silicate $(\mathrm{Si})$, and $\mathrm{NH}_{4}^{+}$) are given as the depth-integrated values in the euphotic zones, with a unit of $\mathrm{mmol} \mathrm{m}{ }^{-2}$. The DIN : $\mathrm{P}$ is the nutrient stoichiometry calculated from the available nutrient data.

\begin{tabular}{|c|c|c|c|c|c|c|c|c|c|c|c|c|c|c|}
\hline Sector & $\begin{array}{l}\text { Stn. } \\
\text { name }\end{array}$ & Longitude & Latitude & Date & $\begin{array}{r}\text { Station } \\
\text { depth }\end{array}$ & $\begin{array}{r}\text { Euphotic } \\
\text { depth }\end{array}$ & SST & SSS & SIC & $\mathrm{NO}_{2}^{-}+\mathrm{NO}_{3}^{-}$ & $\mathrm{P}$ & $\mathrm{Si}$ & $\mathrm{NH}_{4}^{+}$ & DIN : P \\
\hline \multirow[t]{13}{*}{ Laptev Sea } & AF005 & 109.20 & 78.78 & 25 Aug 2013 & 283 & 38 & -0.08 & 31.42 & 0 & 142 & 17.30 & 184 & 31.34 & 10.00 \\
\hline & AF006 & 118.45 & 77.59 & 26 Aug 2013 & 1244 & 50 & 0.75 & 31.36 & 0 & 129 & 16.73 & 158 & 18.72 & 8.81 \\
\hline & AF011 & 125.80 & 77.40 & 27 Aug 2013 & 1543 & 51 & 1.62 & 30.01 & 0 & 83.7 & 23.82 & 137 & 2.46 & 3.62 \\
\hline & AF019 & 125.74 & 79.42 & 28 Aug 2013 & 3196 & 60 & -1.6 & 32.44 & 25 & 132 & 25.75 & 144 & 13.57 & 5.65 \\
\hline & AF024 & 125.69 & 80.72 & 29 Aug 2013 & 3730 & 51 & -1.48 & 30.96 & 45 & 127 & 22.34 & 166 & 13.74 & 6.29 \\
\hline & AF036 & 141.56 & 80.18 & 1 Sep 2013 & 1480 & 54 & -1.22 & 28.29 & 25 & 113 & 7.62 & 207 & 11.85 & 16.39 \\
\hline & AF049 & 137.77 & 78.95 & 5 Sep 2013 & 1552 & 51 & 1.57 & 29.09 & 0 & 22.3 & 9.91 & 100 & 3.44 & 2.60 \\
\hline & AF057 & 128.83 & 77.98 & 5 Sep 2013 & 2325 & 51 & 1.49 & 30.25 & 0 & 107 & 19.96 & 200 & 5.60 & 5.62 \\
\hline & AF061 & 125.83 & 78.40 & 6 Sep 2013 & 2700 & 51 & -0.07 & 31.39 & 10 & 99.4 & 23.15 & 190 & 8.27 & 4.65 \\
\hline & AF068 & 107.39 & 79.76 & 10 Sep 2013 & 1200 & 33 & -0.35 & 32.57 & 0 & 167 & 34.20 & 110 & 27.64 & 5.70 \\
\hline & AF071 & 112.10 & 82.02 & 11 Sep 2013 & 3530 & 43 & -1.73 & 31.86 & 65 & 166 & 20.81 & 144 & 15.46 & 8.72 \\
\hline & AF072 & 107.48 & 81.44 & 12 Sep 2013 & 3349 & 49 & -1.75 & 32.37 & 40 & 132 & 20.17 & 89.5 & 4.32 & 6.78 \\
\hline & AF080 & 102.31 & 80.60 & 13 Sep 2013 & 315 & 76 & -1.14 & 32.81 & 0 & 107 & 30.23 & 38.8 & 21.68 & 4.27 \\
\hline \multirow[t]{2}{*}{ East Siberian Sea } & AF041 & 149.38 & 79.85 & 2 Sep 2013 & 561 & 51 & -1.57 & 29.86 & 60 & 99.0 & 16.21 & 308 & 19.20 & 7.30 \\
\hline & AF044 & 154.98 & 80.22 & 3 Sep 2013 & 1904 & 35 & -1.67 & 30.91 & 100 & 88.7 & 14.48 & 205 & 17.43 & 7.33 \\
\hline \multirow[t]{4}{*}{ Kara Sea } & AF091 & 97.55 & 82.30 & 14 Sep 2013 & 2959 & 38 & -1.32 & 33.30 & 0 & 117 & 25.60 & 135 & 17.67 & 5.27 \\
\hline & AF095 & 94.79 & 83.74 & 15 Sep 2013 & 3668 & 68 & -1.76 & 32.36 & 40 & 121 & 35.44 & 165 & 5.23 & 3.56 \\
\hline & AF100 & 90.01 & 83.75 & 16 Sep 2013 & 3410 & 46 & -1.49 & 33.29 & 0 & 189 & 29.02 & 118 & 6.62 & 6.75 \\
\hline & AF116 & 66.87 & 81.34 & 19 Sep 2013 & 530 & 46 & 0.47 & 33.44 & 0 & 105 & 20.52 & 19.5 & 22.62 & 6.22 \\
\hline
\end{tabular}

tainties for the $\delta^{13} \mathrm{C}$ and $\delta^{15} \mathrm{~N}$ measurements were $\pm 0.1 \%$ 。 and $\pm 0.3 \%$, respectively. The DIN uptake rates of small phytoplankton were estimated using the mathematical formula given by Dugdale and Goering (1967).

DIN uptake rate $=$

$$
P \cdot \Delta I_{\mathrm{p}} /\left(T \cdot\left(I_{0} S_{\mathrm{a}}+I_{r} S_{\mathrm{t}}\right) /\left(S_{\mathrm{a}}+S_{\mathrm{t}}\right)-I_{0}\right),
$$

where $P$ is the amount of particulate $\mathrm{N}$ in the post-incubation sample; $\Delta I_{\mathrm{p}}$ is the increase in ${ }^{15} \mathrm{~N}$ atom\% in particulate $\mathrm{N}$ during incubation; $S_{\mathrm{a}}$ and $S_{\mathrm{t}}$ are the ambient and added $\mathrm{NO}_{3}^{-}$ (or $\mathrm{NH}_{4}^{+}$) concentrations, respectively; $I_{r}$ and $I_{0}$ are ${ }^{15} \mathrm{~N}$ atom\% of added tracer and natural ${ }^{15} \mathrm{~N}$ atom\%; and $T$ is the incubation time period. This equation assumes no formation of nutrients during incubation; therefore, the rates presented here are the potential rates. Similarly, the $\mathrm{C}$ uptake rates were also calculated using the same equation, where $P$ denotes the particulate organic C, and $S_{\mathrm{a}}$ and $S_{\mathrm{t}}$ are the ambient dissolved inorganic carbon and added ${ }^{13} \mathrm{C}$ tracer concentrations, respectively. $I_{r}$ and $I_{0}$ are the ${ }^{13} \mathrm{C}$ atoms $\%$ of the added tracer and natural ${ }^{13} \mathrm{C}$ atom\%, respectively (Slawyk et al., 1977).

\section{Results and discussion}

\subsection{Environmental parameters in the Arctic Ocean}

The biological, chemical, and physical properties of the Arctic Ocean are mainly controlled by the circulation patterns governed by the waters of the Pacific and Atlantic oceans (Anderson et al., 2004; Quadfasel, 2005) along with the river inputs (Peterson et al., 2002). The nutrient-rich, low saline $(<33)$ Pacific Ocean waters and nutrient-replete relatively more saline $(\approx 34.8)$ Atlantic Ocean waters collectively regulate the biogeochemical activities of the Arctic Ocean (Maslowski et al., 2004). The present study was conducted during the late summer season, when the sea surface temperature (SST) ranged from -1.76 to $1.62^{\circ} \mathrm{C}$. The sea surface salinity (SSS) during the study period varied from 28.29 to 33.44 (Table 1), which could be due to the influence of both the circulation patterns and the freshwater inputs. The present study retrieved the sea ice concentration (SIC) data from the National Snow \& Ice Data Center, which obtained the data from a 2013 cruise. The results show that the SIC ranged from $0 \%$ to $100 \%$ (Table 1 ).

\subsection{Carbon and nitrogen uptake rates by small phytoplankton}

Figure 2 shows the depth profiles of the $\mathrm{C}, \mathrm{NO}_{3}^{-}$, and $\mathrm{NH}_{4}^{+}$ uptake rates per hour in the Laptev, Kara, and East Siberian seas. Only a few stations showed significant subsurface maxima for the $\mathrm{C}, \mathrm{NO}_{3}^{-}$, and $\mathrm{NH}_{4}^{+}$uptake rates during the present study, while the rest of the stations exhibited no significant variation throughout the euphotic zone. The AF019 station showed exceptionally higher $\mathrm{C}, \mathrm{NO}_{3}^{-}$, and $\mathrm{NH}_{4}^{+}$uptake rates, in general, with sharp subsurface maxima. The depth-integrated $\mathrm{C}, \mathrm{NO}_{3}^{-}$, and $\mathrm{NH}_{4}^{+}$uptake rates by small phytoplankton in the East Siberian Sea were observed to be very low compared to those of the other seas (Table 2, Figs. 3 and 4). The depth-integrated $C$ uptake rates by small phytoplankton ranged from 0.54 to $15.96 \mathrm{mg} \mathrm{C} \mathrm{m}^{-2} \mathrm{~h}^{-1}$. 


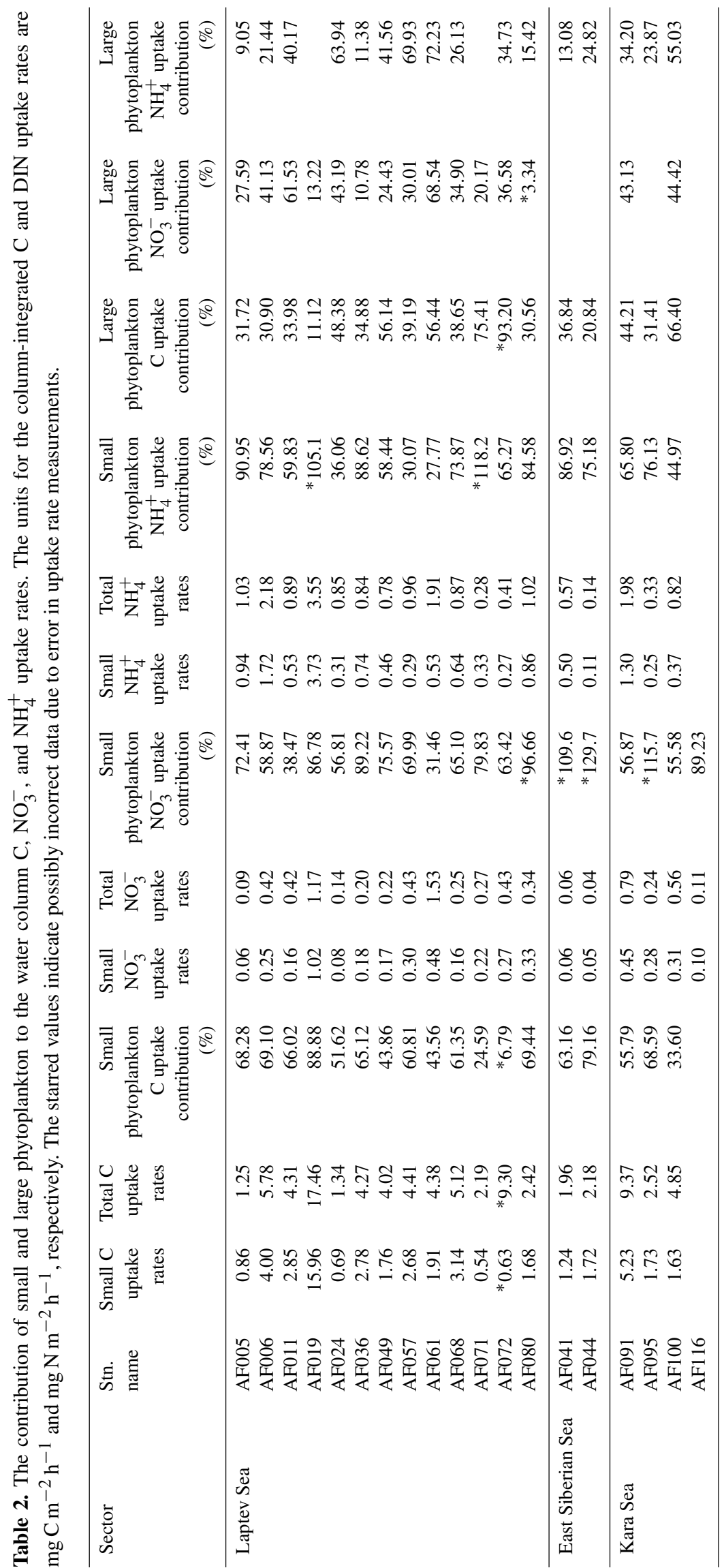



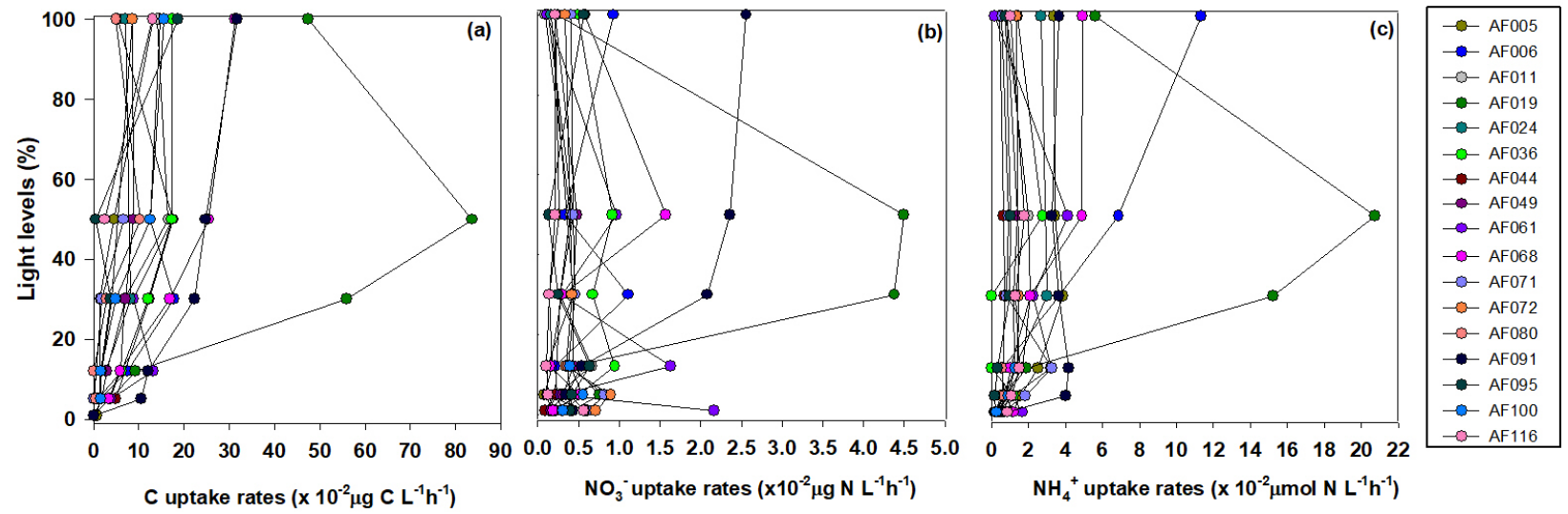

Figure 2. Depth-wise small phytoplankton uptake rates of $\mathrm{C}, \mathrm{NO}_{3}^{-}$, and $\mathrm{NH}_{4}^{+}$in the Kara, Laptev, and East Siberian seas.

The depth-integrated $\mathrm{NO}_{3}^{-}$uptake rates ranged from 0.05 to $1.02 \mathrm{mg} \mathrm{N} \mathrm{m}^{-2} \mathrm{~h}^{-1}$, while the $\mathrm{NH}_{4}^{+}$uptake rates varied from 0.11 to $3.73 \mathrm{mg} \mathrm{N} \mathrm{m}^{-2} \mathrm{~h}^{-1}$. Station AF019 showed the maximum small phytoplankton uptake rates for $\mathrm{C}$ $\left(15.96 \mathrm{mg} \mathrm{C} \mathrm{m}^{-2} \mathrm{~h}^{-1}\right), \mathrm{NO}_{3}^{-}\left(1.02 \mathrm{mg} \mathrm{N} \mathrm{m}^{-2} \mathrm{~h}^{-1}\right)$, and $\mathrm{NH}_{4}^{+}$ (3.73 $\mathrm{mg} \mathrm{N} \mathrm{m}^{-2} \mathrm{~h}^{-1}$ ). The contribution of small phytoplankton to the total uptake was also very high at station AF019 (Table 2). The lowest $\mathrm{C}, \mathrm{NO}_{3}^{-}$, and $\mathrm{NH}_{4}^{+}$uptake rates were observed at stations AF044 and AF041. The highest SIC (100\% and $60 \%$ at AF044 and AF041, respectively) in this region might be one explanation for the lower primary productivity due to light limitation.

\subsection{Sea ice and small phytoplankton primary production}

Previous investigations on SIC over the Arctic Ocean proved that, during winter, high ice formation leads to the expelling of salt content to the surrounding water. This condition introduces a relatively higher salinity and density water layer at the surface or just below the sea ice layer relative to the surrounding area. Such conditions lead to the sinking of the very cold and saline surface waters and the replacement by nutrient-rich deeper water, which is less dense and slightly warmer. This process leads to deep vertical mixing and the replenishment of the surface nutrient inventories (Niebauer et al., 1990; Falk-Petersen et al., 2000). However, during spring, the melting of sea ice results in strong surface ocean stratification, where the nutrient-rich waters are exposed to light, creating favorable conditions for phytoplankton growth (Kirk, 1983; Niebauer et al., 1990; Falk-Petersen et al., 2000). It has also been reported that the increasing atmospheric temperature due to global warming has caused a considerable reduction in SIC in the Arctic Ocean over the past 3 decades, with a rapid decrease in recent years (Parkinson et al., 1999; Levi, 2000).
Because ice cover has a significant role in controlling primary production, the dynamics of SIC is an integral part of Arctic Ocean research (Arrigo et al., 2008; Ardyna et al., 2014; Kahru et al., 2016). It has been reported that a reduction in SIC would facilitate photosynthetic activity and increase $\mathrm{CO}_{2}$ intake by the seas (Anderson and Kaltin, 2001; Bates et al., 2006; Kahru et al., 2016). Apparently, it can cause a relative decline in the contribution by algae growing within the sea ice (Subba Rao and Platt, 1984; Legendre et al., 1992; Gosselin et al., 1997), although the sea ice community contributes less than $10 \%$ to the total amount of Arctic Ocean C sequestration (Clasby et al., 1973; Horner and Schrader, 1982). A detailed study conducted on the interannual variations in SIC and primary production by Kahru et al. (2016) suggested that primary production is enhanced with a decline in SIC. Kahru et al. (2016) reported that a decrease in the SIC initially starts from June onwards in the northeastern Barents Sea and between Greenland and the North American continent, with an increase in primary productivity. This extends to the Kara and Laptev seas during July and August, and these areas exhibit a gradual enhancement in primary productivity. Furthermore, this process migrates towards the region off Siberia and eventually into the Beaufort and Chukchi seas. However, the major enhancement of primary production generally occurs in the Laptev and Barents seas (Kahru et al., 2016). In agreement with this, our results also show relatively lower SIC and higher small phytoplankton C and DIN uptake rates in the Laptev Sea region (Table 2, Figs. 3 and 4). The maximum SIC in the Laptev Sea was observed at station AF071, with a value of $65 \%$. The Kara Sea was mostly void of ice cover, and only one station (AF095) was observed with an SIC of $40 \%$. Relatively lower small phytoplankton C and DIN uptake rates were observed at both stations in the East Siberian Sea (AF041: $60 \%$ and AF044: $100 \%$ ), where the SIC was observed to be the maximum among all stations. However, there was no significant inverse correlation between small phytoplankton C and DIN uptake rates and SIC found dur- 


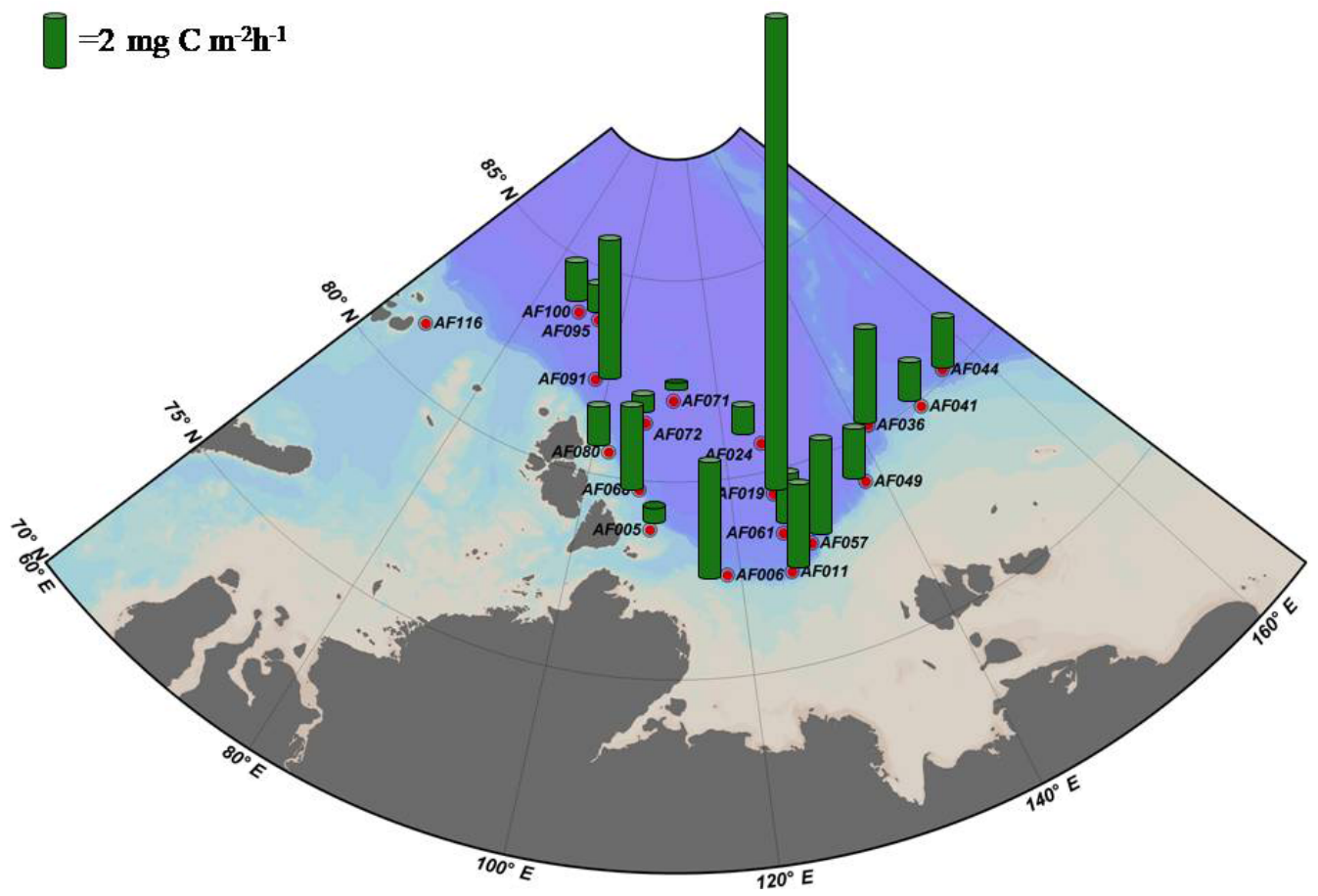

Figure 3. The depth-integrated small phytoplankton $\mathrm{C}$ uptake rates in the sampling locations.

ing the present study (figure not shown). This result could be due to the influence of other environmental constraints, such as low nutrients and temperature, on the metabolic activities of small phytoplankton.

The investigations conducted in the Amundsen Sea, Antarctic Ocean, reported that there is no significant difference in the small phytoplankton $\mathrm{C}$ uptake rates between polynya and non-polynya regions. The depthintegrated small phytoplankton $\mathrm{C}$ uptake rates obtained from polynya and non-polynya regions in the Amundsen Sea ranged from 58.6 to $193 \mathrm{mg} \mathrm{C} \mathrm{m}^{-2} \mathrm{~d}^{-1}$ (126士 $55.2 \mathrm{mg} \mathrm{C} \mathrm{m}^{-2} \mathrm{~d}^{-1}$ ) and from 62.2 to $266 \mathrm{mg} \mathrm{C} \mathrm{m}^{-2} \mathrm{~d}^{-1}$ $\left(124 \pm 69.3 \mathrm{mg} \mathrm{C} \mathrm{m}^{-2} \mathrm{~d}^{-1}\right)$, respectively (Lee et al., 2017a). These values showed that the depth-integrated small phytoplankton $\mathrm{C}$ uptake rates reported from the Amundsen Sea from both polynya and non-polynya regions were relatively higher than those obtained from the Arctic Ocean during the present study $\left(5.86-191 \mathrm{mg} \mathrm{C} \mathrm{m}^{-2} \mathrm{~d}^{-1}\right.$; average $=37.7 \pm 41.6$ ). The daily $\mathrm{NO}_{3}^{-}$uptake rates of the small phytoplankton obtained from the Amundsen Sea were 7.5-26.6 $\mathrm{mg} \mathrm{N} \mathrm{m}^{-2} \mathrm{~d}^{-1}\left(16.7 \pm 7.8 \mathrm{mg} \mathrm{N} \mathrm{m}^{-2} \mathrm{~d}^{-1}\right)$ and $6.1-40.9 \mathrm{mg} \mathrm{N} \mathrm{m}^{-2} \mathrm{~d}^{-1}\left(20.1 \pm 13.1 \mathrm{mg} \mathrm{N} \mathrm{m}^{-2} \mathrm{~d}^{-1}\right)$, and the values of the $\mathrm{NH}_{4}^{+}$uptake rates varied from 9.1 to $22.4 \mathrm{mg} \mathrm{Nm}^{-2} \mathrm{~d}^{-1}\left(15.8 \pm 6.4 \mathrm{mg} \mathrm{N} \mathrm{m}^{-2} \mathrm{~d}^{-1}\right)$ and from 9.9 to $81.1 \mathrm{mg} \mathrm{N} \mathrm{m}^{-2} \mathrm{~d}^{-1}\left(30.7 \pm 24.5 \mathrm{mg} \mathrm{N} \mathrm{m}^{-2} \mathrm{~d}^{-1}\right)$, respectively, for the non-polynya and polynya regions. Similar to the $\mathrm{C}$ uptake rates, the small phytoplankton uptake rates for $\mathrm{NO}_{3}^{-}\left(0.75-12.2 \mathrm{mg} \mathrm{N} \mathrm{m}^{-2} \mathrm{~d}^{-1} ; 3.21 \pm\right.$ $\left.2.61 \mathrm{mg} \mathrm{N} \mathrm{m}^{-2} \mathrm{~d}^{-1}\right)$ and $\mathrm{NH}_{4}^{+}\left(2.68-69.3 \mathrm{mg} \mathrm{N} \mathrm{m}^{-2} \mathrm{~d}^{-1}\right.$; average: $16.12 \pm 14.54 \mathrm{mg} \mathrm{N} \mathrm{m}^{-2} \mathrm{~d}^{-1}$ ) were also significantly lower than those of the Amundsen Sea. The lower small phytoplankton uptake rates in the Arctic waters compared to the Antarctic waters may be due to the lower nutrient concentrations and co-limitation of $\mathrm{N}$ in the Arctic waters (Harrison and Cota, 1991). Sakshaug and HolmHansen (1984) reported that the maximum Arctic nutrient concentrations are typically lower than the minimum Antarctic concentrations.

\subsection{Nutrient sources and influences on small phytoplankton primary production}

The shallow water column depths and the existence of long coastlines along with river runoff provide a wide opportunity for autotrophs in the Arctic Ocean to obtain sufficient light and nutrients (Kirk, 1983). Additionally, the Arctic Ocean is known to be a large receptor of freshwater discharge that exceeds $4000 \mathrm{~km}^{3}$ per year (Shiklomanov et al., 2000; Carmack and Macdonald, 2002). The riverine discharges may have a great role in keeping those stations near river inlets distinctive in terms of their physico-chemical conditions. Similarly, the freshwater discharge from the six largest Eurasian rivers increased by $7 \%$ during the period of 1936-1999 (Peterson et al., 2002). Among the various seas in the Arctic Ocean, the Kara and Laptev seas are known to be the first and second largest receptors, respectively, of total organic carbon fluxes, while the East Siberian Sea receives the least (Rachold et al., 2000). 


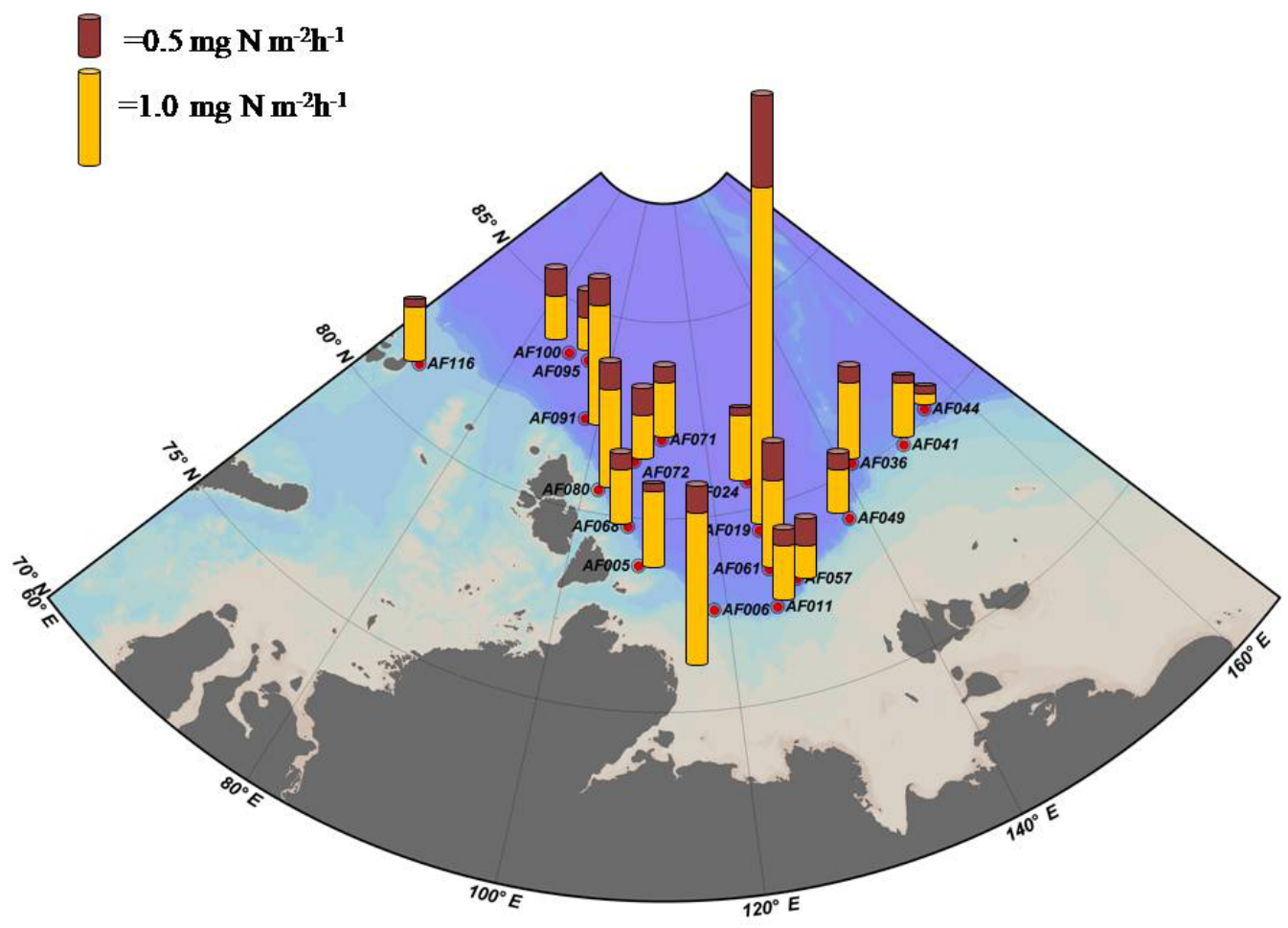

Figure 4. The depth-integrated small phytoplankton $\mathrm{NO}_{3}^{-}$and $\mathrm{NH}_{4}^{+}$uptake rates in the sampling locations. The maroon and yellow cylinders indicate the small phytoplankton $\mathrm{NO}_{3}^{-}$and $\mathrm{NH}_{4}^{+}$depth-integrated uptake rates, respectively.

In most stations, the $\mathrm{NO}_{2}^{-}+\mathrm{NO}_{3}^{-}$concentrations were observed to be homogeneous in the water column up to a depth of $20 \mathrm{~m}$ (approximately $30 \%$ light depth); however, they increased exponentially towards the bottom waters (figure not shown). The depth profiles of $\mathrm{NH}_{4}^{+}$and $\mathrm{P}$ did not show any significant variation throughout the euphotic zone (figure used in Lee et al., unpublished data). However, the nutrient concentrations were considerably distinct among the stations. The depth-integrated $\mathrm{NO}_{2}^{-}+\mathrm{NO}_{3}^{-}$concentrations varied between 22.3 and $189 \mathrm{mmol} \mathrm{m}^{-2}$. The depth-integrated concentrations of $\mathrm{P}$ and $\mathrm{Si}$ ranged from 7.62 to 35.4 and 19.5 to $308 \mathrm{mmol} \mathrm{m}^{-2}$, respectively (Table 1). Generally, high concentrations of $\mathrm{NO}_{2}^{-}+\mathrm{NO}_{3}^{-}$and phosphate were found at the AF005, AF068, and AF071 stations in the Laptev Sea and at one station in the Kara Sea (AF100), and they were relatively higher than those of the East Siberian Sea (Table 1, Figs. 3 and 4). However, the Si concentrations were higher in the East Siberian Sea than in the other two seas. These results are comparable with the earlier studies conducted by Codispoti and Richards (1968). They suggested that the concentrations of $\mathrm{P}$ and $\mathrm{NO}_{3}^{-}$were so low as to indicate nutrient limitation for phytoplankton production in the upper layers.

The details of the euphotic depths and the depth-integrated nutrient concentrations are shown in Table 1. The euphotic depths observed are different in almost all of the stations and range from 33 to $76 \mathrm{~m}$. However, the data from our present study did not show any dependency of the depth- integrated nutrient budget with euphotic depth. For example, the AF019, AF080, and AF095 stations have deeper euphotic zones; however, they do not have depth-integrated $\mathrm{NO}_{2}^{-}+\mathrm{NO}_{3}^{-}$concentrations close to the highest values obtained at the AF068, AF071, and AF005 stations, which have relatively shallower euphotic depths. The depth-integrated $P$ values also showed higher values at stations (AF019, AF068, AF100, AF080, AF095, and AF091) with both deeper and shallower euphotic depths. Hence, the variation in the euphotic depth seems to be insignificant in determining the nutrient budgets in the present study area.

Stations AF005, AF068, and AF071 in the Laptev Sea and AF100 in the Kara Sea, which were nearby the river inlets, were observed to have relatively higher nutrient concentrations (Table 1). The sampling locations away from the river inputs were mostly invaded by the nutrient-poor Atlantic waters instead of the nutrient-rich Pacific waters. Moreover, the Pacific Ocean nutrient inputs are generally restricted to the Chukchi Sea and the Amerasian Basin (Carmack et al., 1997; Dmitrenko et al., 2006). It is worth noting that all the sampling locations in the Arctic Ocean showed significantly lower small phytoplankton C and DIN uptake rates, possibly due to the lack of light and nutrients. The nutrient stoichiometry analyses suggested that the Arctic Ocean waters are $\mathrm{N}$ starved and the $\mathrm{N}: \mathrm{P}$ (here $\mathrm{N}=\mathrm{DIN}: \mathrm{NO}_{2}^{-}+\mathrm{NO}_{3}^{-}+\mathrm{NH}_{4}^{+}$ and $\mathrm{P}: \mathrm{PO}_{4}^{3-}$ ) ratios are always below Redfield's ratio, which 
is $16: 1$ (mol: mol) (Redfield, 1963; Sakshaug, 2004). The relative abundances of micronutrients are also important factors in controlling primary production (Glibert et al., 2013; Bhavya et al., 2016, 2017). The DIN : P observed during the current study ranged from 2.60 to 16.4 , with an average of $6.6 \pm 3.0$, which is also in agreement with the previous studies that have been reported. These ratios point towards the $\mathrm{N}$ starvation of phytoplankton, which can potentially prevent them from growing to a bloom. It has been reported that such cases with lower nutrient concentrations are generally less starving for small phytoplankton sizes ranging from 0.7 to $5 \mu \mathrm{m}$, and they appeared to be dominant in euphotic water columns (Lee and Whitledge, 2005; Li et al., 2009; Yun et al., 2015).

In general, experimental and theoretical evidence suggests that smaller cells have higher rates of nutrient uptake per unit biomass and lower half-saturation constants due to their higher surface area to volume ratios (Eppley and Thomas, 1969; Aksnes and Egge, 1991; Hein et al., 1995). Hence, the lower minimum cellular metabolic requirement for small phytoplankton selectively allows them to survive under lower resource concentrations than those of larger cells (Shuter, 1978; Grover, 1991). Hence, small phytoplankton cells appear to have substantial advantages over larger phytoplankton cells under nutrient-limited steady-state environmental conditions (Grover, 1989, 1991). However, under very poor nutrient conditions, small phytoplankton may also undergo nutrient starvation.

\subsection{Nutrient co-limitation}

Nutrient co-limitation is a major problem facing marine phytoplankton in oligotrophic and pelagic ecosystems. Recent studies have suggested that the maximum uptake of phytoplankton generally occurs when the nutrient stoichiometry is close to Redfield's ratio, which is $16: 1$ (Li et al., 2011; Glibert et al., 2013; Bhavya et al., 2016, 2017), irrespective of the individual nutrient concentration. Because the present study addresses completely different ecosystems with high SIC, low nutrients, and low SSTs, understanding the influence of DIN : P would be challenging. In agreement with this, there were no significant correlations observed between the $\mathrm{C}, \mathrm{NO}_{3}^{-}$, and $\mathrm{NH}_{4}^{+}$uptake rates and the DIN : $\mathrm{P}$ during the present study. However, Fig. 5 shows a weak, although positive, correlation of small phytoplankton contribution towards DIN : P. This result indicates the possibility of small phytoplankton efficiency peaking at a nutrient stoichiometry close to Redfield's ratio. However, the lack of sufficient stations with higher DIN : P values limits the present study from claiming the influence of nutrient stoichiometry on the small phytoplankton contribution. It is also important to note that the stations are located at geographical locations with diverse hydrographical parameters. However, on the basis of a few studies conducted from various parts of oceanic and estuarine regions, it has been shown that DIN : $\mathrm{P}$ has a strong control

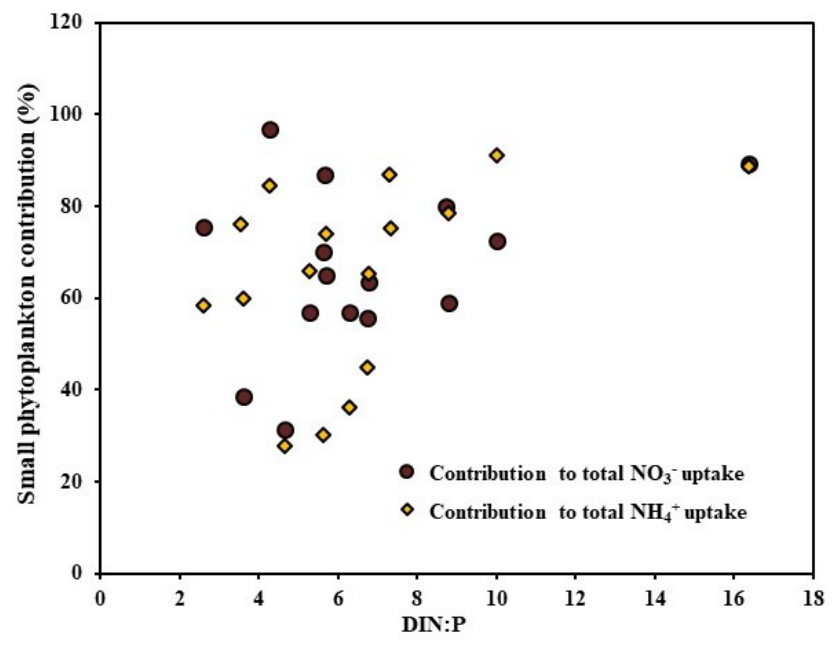

Figure 5. The relationship of the contribution of small phytoplankton towards the total $\mathrm{NO}_{3}^{-}$and $\mathrm{NH}_{4}^{+}$uptake rates with DIN : $\mathrm{P}$.

on the total C and DIN uptake rates (Li et al., 2011; Glibert et al., 2013; Bhavya et al., 2016, 2017). Although there was no significant correlation obtained between the small phytoplankton uptakes and the DIN:P, the $\mathrm{N}$ co-limitation in the Arctic Ocean is clearly seen (Table 1). Thus, the relative abundances of DIN and $\mathrm{P}$ are highly important for the proper functioning of the $\mathrm{C}$ and DIN uptake mechanisms by autotrophs.

\subsection{Turnover times of nutrients}

The present study shows that $\mathrm{N}$ co-limitation persists in the Arctic Ocean and can potentially limit the small phytoplankton contribution. In that case, any inorganic $\mathrm{N}$ substrate introduced to the surface waters might be immediately used by the phytoplankton to facilitate organic matter production under favorable environmental conditions. The turnover time for any substrate is an important measurement to estimate how rapidly an $\mathrm{N}$ substrate can be consumed. The estimation of turnover time is performed by dividing the substrate concentrations by the corresponding uptake rates. Figures 6 and 7 show the turnover times for the $\mathrm{NO}_{3}^{-}$and $\mathrm{NH}_{4}^{+}$substrates when small phytoplankton communities are the only consumers. Figure 7 shows that the turnover times for the $\mathrm{NH}_{4}^{+}$substrate (within $500 \mathrm{~h}$ ) in the surface waters are longer; however, they are relatively faster than those of the $\mathrm{NO}_{3}^{-}$in the upper layers of the euphotic zone at almost all the stations in the Arctic Ocean. However, the bottom waters of the euphotic zone showed relatively longer $(1000-1700 \mathrm{~h})$ turnover times for $\mathrm{NH}_{4}^{+}$substrate compared to the surface waters. The sampling location in the East Siberian Sea (AF044) was observed to have relatively longer turnover times for both $\mathrm{NO}_{3}^{-}$ and $\mathrm{NH}_{4}^{+}$substrates at the surface layers (Figs. 6 and 7), which was possibly due to the lower uptake rates in that region. A continuous supply of nutrients through rivers and less 


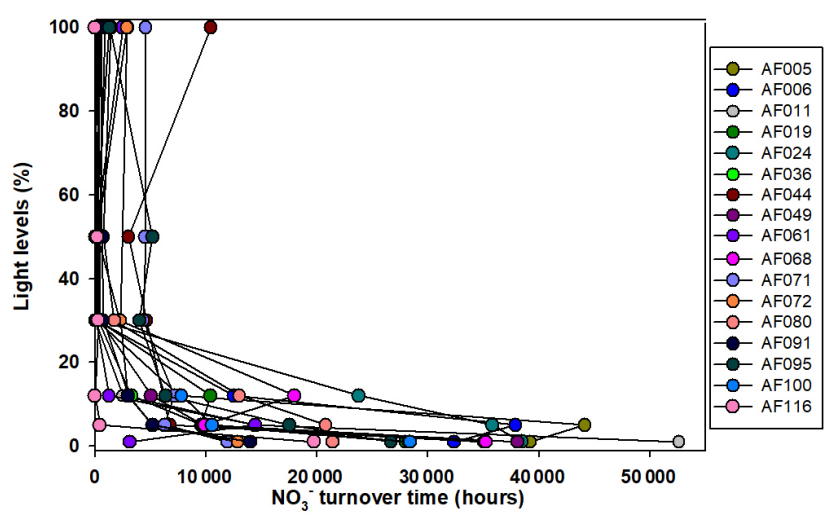

Figure 6. Turnover times for the $\mathrm{NO}_{3}^{-}$substrate, when small phytoplankton are the only consumers, in the sampling locations in the Arctic Ocean.

efficient DIN uptake rates might be major reasons for longer turnover times. Compared to $\mathrm{NH}_{4}^{+}, \mathrm{NO}_{3}^{-}$is consumed in distinctively longer periods as 14 -fold at the surface waters and 25 -fold at the bottom of the euphotic zone. Primarily, such a difference is due to the relative preference for $\mathrm{NH}_{4}^{+}$by the small phytoplankton and, second, due to the high concentrations of $\mathrm{NO}_{3}^{-}$in the deep waters relative to the $\mathrm{NH}_{4}^{+}$concentrations. The research outputs from a tropical eutrophic estuary in India have shown rapid turnover time (3.4-232 $\mathrm{h}$ for $\mathrm{NH}_{4}^{+}$and 7.13-2419 $\mathrm{h}$ for $\mathrm{NO}_{3}^{-}$) by total phytoplankton communities for DIN substrates despite higher nutrient concentrations (Bhavya et al., 2016). In general, inhibition of $\mathrm{NO}_{3}^{-}$ uptake is a very common phenomenon when higher $\mathrm{NH}_{4}^{+}$ concentrations occur (e.g., Glibert, 1982; Harrison et al., 1987; McCarthy et al., 1999; Bhavya et al., 2016). It is also very likely there will be different turnover times with similar DIN concentrations under different hydrographic properties that can govern the $\mathrm{C}$ and DIN metabolism in a given region.

\subsection{Quantum yield}

During the present study, the size-fractionated $\mathrm{Chl} a$ concentrations at the three light levels $(100 \%, 30 \%$, and $1 \%)$ were measured. The comparative analysis with the total $\mathrm{Chl} a$ fraction suggests that the small phytoplankton communities are major contributors in the Laptev, Kara, and East Siberian seas (figure not shown; data used from Lee et al., unpublished data). The results showed significantly high contributions of small phytoplankton to total Chl $a$ at all three light levels $(63.3(\mathrm{SD}= \pm 17.5 \%), 61.4(\mathrm{SD}= \pm 19.9 \%)$, and $59.0 \%$ $(\mathrm{SD}= \pm 18.4 \%)$ at $100 \%, 30 \%$, and $1 \%$, respectively).

The ability of Chl $a$ to fix C and DIN in small phytoplankton communities is a matter of concern in the Arctic Ocean. The quantum yield for the present study is defined as the efficiency of unit $\mathrm{Chl} a$ in the small phytoplankton communities in fixing DIN and $\mathrm{C}$, which is calculated by dividing the uptake rates by the $\mathrm{Chl} a$ concentration. The lower temperatures

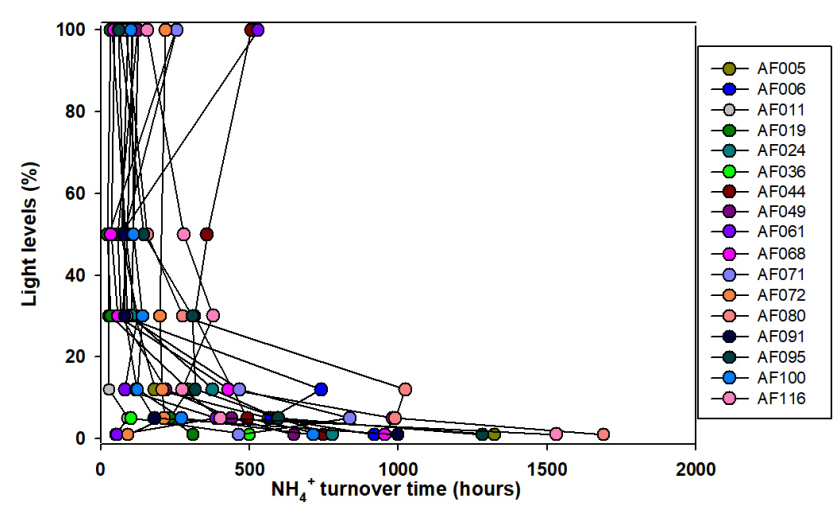

Figure 7. Turnover times for the $\mathrm{NH}_{4}^{+}$substrate, when small phytoplankton are the only consumers, in the sampling locations.

and salinities, ice cover, and poor light availability can potentially lower the quantum yields. The quantum yields for the $\mathrm{C}$ and DIN are shown in Figs. 8 and 9, respectively. The maximum yields for both C and DIN were observed at AF091 for the $100 \%$ and $30 \%$ light depths. However, the quantum yield for $\mathrm{C}$ at the $1 \%$ light level in all stations was observed to be very low, more likely due to light limitation (Talling, 1957). Although the quantum yield for DIN was lower at $1 \%$ than at the other two light levels, a drastic drop in the quantum yield for DIN at the $1 \%$ light level, such as quantum yield for C, was not observed. This result can be due to the existence of significant $\mathrm{NH}_{4}^{+}$uptake rates in the light-scarce conditions.

\subsection{Small and large phytoplankton contributions}

It is known that the impact of global warming on the Arctic Ocean has introduced rapid changes in its physicochemical properties. Hence, the necessity to trace the changes in primary production patterns in the Arctic Ocean has gained attention in the recent era. It has been reported that the contribution of small phytoplankton to the total C and DIN fixations would increase under warming conditions ( $\mathrm{Li}$ et al., 2009; Thomas et al., 2012). A significant number of total primary production estimates are available from the Arctic Ocean (Platt et al., 1982; Vedernikov et al., 1994; Gosselin et al., 1997; Boetius and Damm, 1998; Tremblay et al., 2002; Arrigo et al., 2008; Wassmann et al., 2011; Arrigo and van Dijken, 2011; Yun et al., 2012, 2015; Kahru et al., 2016; Lee et al., 2007, 2012, 2017a; Lee et al., unpublished data). However, a deep understanding regarding the boosting of small phytoplankton under warming conditions and their contributions towards the total primary production is still rudimentary. The present study provides the first report on small phytoplankton contributions to the total primary production in the Kara, Laptev, and East Siberian seas in the Arctic Ocean. The results from the study suggest that the small phytoplankton potentially contributed $24 \%$ to $89 \%, 32 \%$ to $89 \%$, and $28 \%$ to $91 \%$ to the total $\mathrm{C}, \mathrm{NO}_{3}^{-}$, and $\mathrm{NH}_{4}^{+}$uptake rates, 


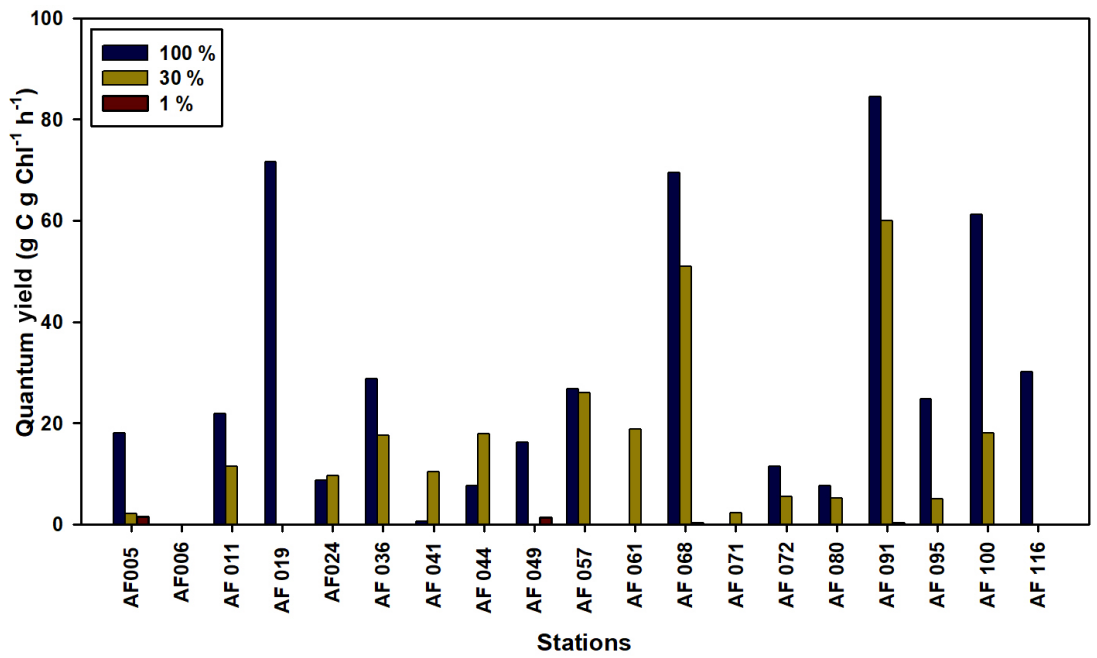

Figure 8. Quantum carbon yield of small phytoplankton in the sampling locations.

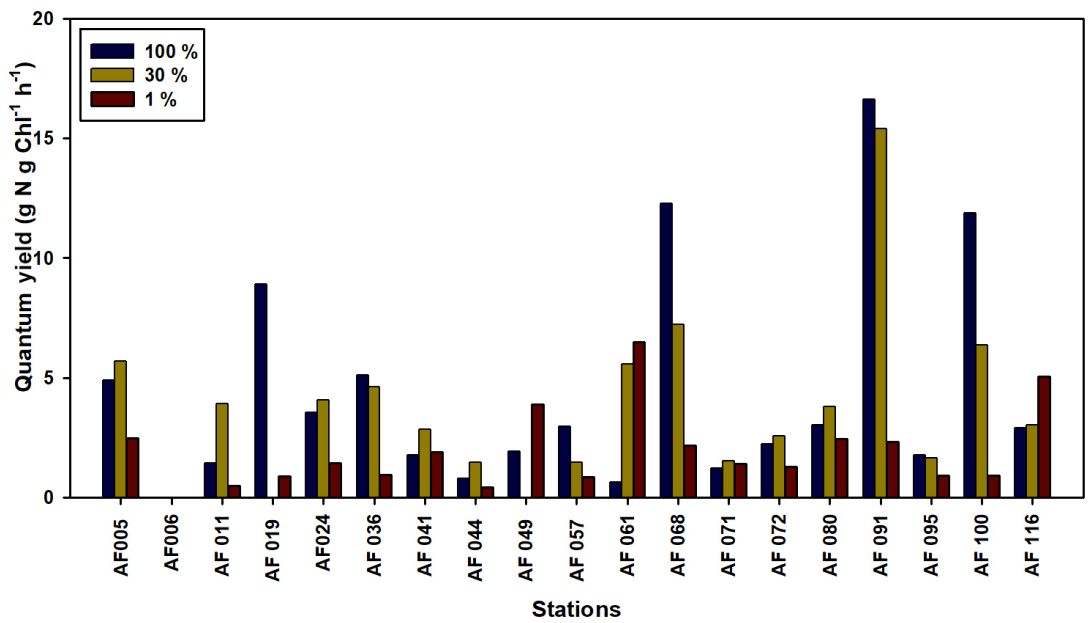

Figure 9. Quantum nitrogen yield of small phytoplankton in the sampling locations.

respectively, in the whole study region. Studies from various oceanic bodies suggest that the small phytoplankton contribution to the total annual $\mathrm{C}$ and DIN fixation varies between $20 \%$ and $65 \%$ (Agawin et al., 2000; Hodal and Kristiansen, 2008; Joo et al., 2017; Lee et al., 2017a). The contributions of small phytoplankton to total $\mathrm{C}$ uptake rates were significantly higher in the Amundsen Sea, with an average of $50.8 \%( \pm 42.8 \%)$ and $14.9 \%( \pm 8.4 \%)$, respectively, for the non-polynya and polynya regions (Lee et al., 2017a). The contributions of small phytoplankton to the total $\mathrm{NO}_{3}^{-}$ uptake rates were $28.2 \%( \pm 15.9 \%)$ in the non-polynya region and $18.1 \%( \pm 6.8 \%)$ in the polynya region. Similar to the $\mathrm{C}$ assimilation rates, the small phytoplankton contributions to the total $\mathrm{NH}_{4}^{+}$uptake rates were higher in both nonpolynya $(52.8 \% ; \pm 40.5 \%)$ and polynya $(31.6 \% ; \pm 10.1 \%)$ regions (Lee et al., 2017a). Similarly, the small phytoplankton contribution in the western Canada basin in the Arctic
Ocean was reported to be $64 \%$ (Yun et al., 2015). A recent study from the Chukchi Sea reported that the average contributions of small phytoplankton to the $\mathrm{C}$ and total DIN uptake rates were approximately $32 \%(\mathrm{SD}= \pm 24 \%)$ and $37 \%$ $(\mathrm{SD}= \pm 26 \%$ ), respectively (Lee et al., 2013). Similar investigations conducted in the northern Barents Sea found that small phytoplankton contributed almost half $(46 \%)$ of the total primary production (Hodal and Kristiansen, 2008). The MODIS-derived data in the Ulleung Basin from 2003 to 2012 suggested that the annual contribution by small phytoplankton communities, in general, ranged from $19.6 \%$ to $28.4 \%$, with an average of $23.6 \%$ ( $\mathrm{SD}= \pm 8.1 \%$ ) (Joo et al., 2017). This study suggested that large phytoplankton communities are the major contributors to primary production in the Ulleung Basin. Similarly, Legendre et al. (1992) reported that primary production in the high-latitude Arctic region waters, in general, was dominated by large phytoplankton cells 
( $>5 \mu \mathrm{m}$ ), while the standing stock was dominated by small cell-sized phytoplankton $(0.7-5 \mu \mathrm{m})$ due to strong grazing stress on large cells. The present study also estimated large phytoplankton contributions (total small phytoplankton contributions) to the total uptake rates (Table 2). The assessments by Tremblay et al. (2000) suggested that large phytoplankton can fix relatively more $\mathrm{C}$ per unit $\mathrm{NO}_{3}^{-}$and thus export more $\mathrm{C}$ than can small phytoplankton. However, the results from the present study showed that the large phytoplankton communities in the Arctic Ocean could contribute only an average of $40 \%, 34 \%$, and $35 \%$ to the total $\mathrm{C}_{2} \mathrm{NO}_{3}^{-}$, and $\mathrm{NH}_{4}^{+}$uptake rates, respectively. Hence, small phytoplankton appear to be the major contributors of $\mathrm{C}, \mathrm{NO}_{3}^{-}$, and $\mathrm{NH}_{4}^{+}$uptake, with percentage contributions of $60 \%, 66 \%$, and $65 \%$, respectively, in the Laptev, Kara, and East Siberian seas. These values are much higher than the global average contribution (39\%) of small phytoplankton production, as assessed by Agawin et al. (2000).

\section{Conclusions}

The present study attempted to estimate small phytoplankton contributions towards the total $\mathrm{C}, \mathrm{NO}_{3}^{-}$, and $\mathrm{NH}_{4}^{+}$uptake rates in the Kara, Laptev, and East Siberian seas. The contributions of small phytoplankton to the total $\mathrm{C}, \mathrm{NO}_{3}^{-}$, and $\mathrm{NH}_{4}^{+}$uptake rates ranged from $25 \%$ to $89 \%$, from $31 \%$ to $89 \%$, and from $28 \%$ to $91 \%$, respectively, in the Arctic Ocean. There was no significant influence of ice cover on uptake rates; however, the stations with high SIC generally showed low surface small phytoplankton uptake of $\mathrm{C}$, $\mathrm{NO}_{3}^{-}$, and $\mathrm{NH}_{4}^{+}$. It was also observed that the DIN : $\mathrm{P}$ can potentially play a major role in controlling the small phytoplankton contributions towards the DIN uptake rates by small phytoplankton. The significant contributions of small phytoplankton indicate their efficiency in withstanding hostile conditions, such as low nutrients, changing SST, and high ice cover. However, to understand the influence of global warming on small phytoplankton activity, growth, and community shifts, long-term in situ analyses as well as laboratory manipulations and experiments are highly recommended.

Data availability. Data are available and can be requested from the corresponding author (sanglee@pusan.ac.kr).

Author contributions. PSB and SHL are responsible for the overall preparation and data analysis of this paper. SHL and TEW designed the overall study. JanHL, HWL, and SHA measured in situ primary productivity and DAS and TEW analyzed chlorophyll- $a$ concentrations and major inorganic nutrient concentrations during the cruise. JJK, JaeHL, and DL helped with data analysis and manuscript preparation.
Competing interests. The authors declare that they have no conflict of interest.

Acknowledgements. We thank the captain and crew of the Akademik Fedorov for their outstanding assistance during the cruise. We are also thankful to the anonymous reviewers for their suggestions and comments. This research was supported by the Korea Research Foundation (KRF) grant funded by the Korean government (NRF-2016R1A2B4015679). Support for Terry E. Whitledge and Dean A. Stockwell was provided by NSF grant no. 120347.

Edited by: Gerhard Herndl

Reviewed by: two anonymous referees

\section{References}

Agawin, N. S., Duarte, C. M., and Agustí, S.: Nutrient and temperature control of the contribution of picoplankton to phytoplankton biomass and production, Limnol. Oceanogr., 45, 591-600, 2000.

Anderson, L. G. and Kaltin, S.: Carbon fluxes in the Arctic Oceanpotential impact by climate change, Polar Res., 20, 225-232, 2001.

Anderson, L. G., Jutterström, S., Kaltin, S., Jones, E. P., and Björk, G.: Variability in river runoff distribution in the Eurasian Basin of the Arctic Ocean, J. Geophys. Res.-Oceans, 109, https://doi.org/10.1029/2003JC001773, 2004.

Anderson, L. G., Jutterström, S., Hjalmarsson, S., Wåhlström, I., and Semiletov, I.: Out-gassing of $\mathrm{CO}_{2}$ from Siberian Shelf seas by terrestrial organic matter decomposition, Geophys. Res. Lett., 36, L20601, https://doi.org/10.1029/2009GL040046, 2009.

Aksnes, D. L. and Egge, J. K.: A theoretical model for nutrient uptake in phytoplankton, Mar. Ecol.-Prog. Ser., 70, 65-72, 1991.

Ardyna, M., Babin, M., Gosselin, M., Devred, E., Rainville, L., and Tremblay, J. É.: Recent Arctic Ocean sea ice loss triggers novel fall phytoplankton blooms, Geophys. Res. Lett., 41, 6207-6212, 2014.

Arrigo, K. R. and van Dijken, G. L.: Secular trends in Arctic Ocean net primary production, J. Geophys. Res., 116, C09011, https://doi.org/10.1029/2011JC007151, 2011.

Arrigo, K. R. and van Dijken, G. L.: Continued increases in Arctic Ocean primary production, Prog. Oceanogr., 136, 60-70, 2015.

Arrigo, K. R., van Dijken, G., and Pabi, S.: Impact of a shrinking Arctic ice cover on marine primary production, Geophys. Res. Lett., 35, L19603, https://doi.org/10.1029/2008GL035028, 2008.

Arrigo, K. R., Perovich, D. K., Pickart, R. S., Brown, Z. W., Van Dijken, G. L., Lowry, K. E., Mills, M. M., Palmer, M. A., Balch, W. M., Bahr, F., and Bates, N. R.: Massive phytoplankton blooms under Arctic sea ice, Science, 336, 1408-1408, 2012.

Bates, N. R. and Mathis, J. T.: The Arctic Ocean marine carbon cycle: evaluation of air-sea $\mathrm{CO}_{2}$ exchanges, ocean acidification impacts and potential feedbacks, Biogeosciences, 6, 2433-2459, https://doi.org/10.5194/bg-6-2433-2009, 2009.

Bates, N. R., Moran, S. B., Hansell, D. A., and Mathis, J. T.: An increasing $\mathrm{CO}_{2}$ sink in the Arctic Ocean due to sea-ice loss, Geophys. Res. Lett., 33, L23609, https://doi.org/10.1029/2006GL027028, 2006. 
Bélanger, S., Babin, M., and Larouche, P.: An empirical ocean color algorithm for estimating the contribution of chromophoric dissolved organic matter to total light absorption in optically complex waters, J. Geophys. Res., 13, C04027, https://doi.org/10.1029/2007JC004436, 2008.

Bélanger, S., Babin, M., and Tremblay, J.-É.: Increasing cloudiness in Arctic damps the increase in phytoplankton primary production due to sea ice receding, Biogeosciences, 10, 4087-4101, https://doi.org/10.5194/bg-10-4087-2013, 2013.

Bhavya, P. S., Kumar, S., Gupta, G. V. M., Sudheesh, V., Sudharma, K. V., Varrier, D. S., Dhanya, K. R., and Saravanane, N.: Nitrogen uptake dynamics in a tropical eutrophic estuary (Cochin estuary) and adjacent coastal regions during pre-monsoon, Estuar. Coast., 39, 54-67, https://doi.org/10.1007/s12237-015-9982-y, 2016.

Bhavya, P. S., Kumar, S., Gupta, G. V. M., and Sudheesh, V.: Carbon uptake rates in the Cochin estuary and adjoining coastal Arabian Sea, Estuar. Coast., 40, 447-456, https://doi.org/10.1007/s12237-016-0147-4, 2017.

Boetius, A. and Damm, E.: Benthic oxygen uptake, hydrolytic potentials and microbial biomass at the Arctic continental slope, Deep-Sea Res. Pt. I, 45, 239-275, 1998.

Bopp, L., Monfray, P., Aumont, O., Dufresne, J. L., Le Treut, H., Madec, G., Terray, L., and Orr, J. C.: Potential impact of climate change on marine export production, Global Biogeochem. Cy., 15, 81-99, 2001.

Cai, W. J., Chen, L., Chen, B., Gao, Z., Lee, S. H., Chen, J., Pierrot, D., Sullivan, K., Wang, Y., Hu, X., and Huang, W. J.: Decrease in the $\mathrm{CO}_{2}$ uptake capacity in an ice-free Arctic Ocean basin, Science, 329, 556-559, 2010.

Carmack, E. C. and Macdonald, R. W.: Oceanography of the Canadian Shelf of the Beaufort Sea: a setting for marine life, Arctic, 55, 29-45, 2002.

Carmack, E. C., Aagaard, K., Swift, J. H., MacDonald, R. W., McLaughlin, F. A., Jones, E. P., Perkin, R. G., Smith, J. N., Ellis, K. M., and Killius, L. R.: Changes in temperature and tracer distributions within the Arctic Ocean: Results from the 1994 Arctic Ocean section, Deep-Sea Res. Pt. II, 44, 1487-1502, 1997.

Clasby, R. C., Horner, R., and Alexander, V.: An in situ method for measuring primary productivity of Arctic sea ice algae, J. Fish. Res. Board Can., 30, 835-838, 1973.

Codispoti, L. A. and Richards, F. A.: Micronutrient distributions in the East Siberian and Laptev seas during summer 1963, Arctic, 21, 67-83, 1968.

Comiso, J. C., Parkinson, C. L., Gersten, R., and Stock, L.: Accelerated decline in the Arctic sea ice cover, Geophys. Res. Lett., 35, L01703, https://doi.org/10.1029/2007GL031972, 2008.

Daufresne, M., Lengfellner, K., and Sommer, U.: Global warming benefits the small in aquatic ecosystems, P. Natl. Acad. Sci. USA, 106, 12788-12793, 2009.

Dmitrenko, I. A., Polyakov, I. V., Kirillov, S. A., Timokhov, L. A., Simmons, H. L., Ivanov, V. V., and Walsh, D.: Seasonal variability of Atlantic water on the continental slope of the Laptev Sea during 2002-2004, Earth Planet. Sc. Lett., 244, 735-743, 2006.

Dugdale, R. and Goering, J.: Uptake of new and regenerated forms of nitrogen in primary productivity, Limnol. Oceanogr., 12, 196206, 1967.

Dugdale, R. C. and Wilkerson, F. P.: The use of ${ }^{15} \mathrm{~N}$ to measure nitrogen uptake in eutrophic oceans; experimental considerations, Limnol. Oceanogr., 31, 673-689, 1986.
Eastman, R. and Warren, S. G.: Interannual variations of Arctic cloud types in relation to sea ice, J. Climate, 23, 4216-4232, 2010.

Eppley, R. W. and Thomas, W. H.: Comparison of half-saturation constants for growth and nitrate uptake of marine phytoplankton, J. Phycol., 5, 375-379, 1969.

Falk-Petersen, S., Hop, H., Budgell, W. P., Hegseth, E. N., Korsnes, R., Løyning, T. B., Ørbæk, J. B., Kawamura, T., and Shirasawa, $\mathrm{K}$.: Physical and ecological processes in the marginal ice zone of the northern Barents Sea during the summer melt period, J. Marine Syst., 27, 131-159, 2000.

Glibert, P. M.: Regional studies of daily, seasonal and size fraction variability in ammonium remineralization, Mari. Biol., 70, 209222, 1982.

Glibert, P. M., Kana, T. M., and Brown, K.: From limitation to excess: the consequences of substrate excess and stoichiometry for phytoplankton physiology, trophodynamics and biogeochemistry, and the implications for modeling, J. Marine Syst., 125, 14-28, 2013.

Gosselin, M., Levasseur, M., Wheeler, P. A., Horner, R. A., and Booth, B. C.: New measurements of phytoplankton and ice algal production in the Arctic Ocean, Deep-Sea Res. Pt. II, 44, 1623 1644, 1997.

Gradinger, R.: Sea-ice algae: major contributors to primary production and algal biomass in the Chukchi and Beaufort seas during May/June 2002, Deep-Sea Res. Pt. II, 44, 1623-1644, https://doi.org/10.1016/j.dsr2.2008.10.016, 2009.

Grover, J. P.: Influence of cell shape and size on algal competitive ability, J. Phycol., 25, 402-405, 1989.

Grover, J. P.: Resource competition in a variable environment: phytoplankton growing according to the variable-internal-stores model, Am. Nat., 138, 811-835, 1991.

Harrison, W. G. and Cota, G. F.: Primary production in polar waters: relation to nutrient availability, Polar Res., 10, 87-104, 1991.

Harrison W. G., Li, W. K. W., Smith, J. C., Head, E. J. H., and Longhurst, A. R.: Depth profiles of plankton, particulate organic matter and microbial activity in the Eastern Canadian Arctic during summer, Polar Biol., 7, 207-224, 1987.

Hein, M., Folager Pedersen, M., and Sand-Jensen, K.: Sizedependent nitrogen uptake in micro- and macroalgae, Mar. Ecol.Prog. Ser., 118, 247-253, 1995.

Hill, V., Ardyna, M., Lee, S. H., and Varela, D. E.: Decadal trends in phytoplankton production in the Pacific Arctic Region from 1950 to 2012, Deep-Sea Res. Pt. II, https://doi.org/10.1016/j.dsr2.2016.12.015, in press, 2017.

Hill, V. J. and Cota, G. F.: Spatial patterns of primary production in the Chukchi Sea in the spring and summer of 2002, Deep-Sea Res. Pt. II, 52, 3344-3354, 2005.

Hodal, H. and Kristiansen, S.: The importance of small-celled phytoplankton in spring blooms at the marginal ice zone in the northern Barents Sea, Deep-Sea Res. Pt. II, 55, 2176-2185, 2008.

Horner, R. and Schrader, G. C.: Relative contributions of ice algae, phytoplankton, and benthic microalgae to primary production in nearshore regions of the Beaufort Sea, Arctic, 35, 485503, 1982.

Jakobsson, M. and IBCAO Editorial Board Members: Improvement to the International Bathymetric Chart of the Arctic Ocean (IBCAO): Updating the Data Base and the Grid Model, EOS T. Am. 
Geophys. Un., 82, Fall Meet. Suppl., Abstract no. OS11B-0371, 2001.

Joo, H., Son, S., Park, J. W., Kang, J. J., Jeong, J. Y., Kwon, J. I., Kang, C. K., and Lee, S. H.: Small phytoplankton contribution to the total primary production in the highly productive Ulleung Basin in the East/Japan Sea, Deep-Sea Res. Pt. II, 143, 54-61, 2017.

Kahru, M., Lee, Z., Mitchell, B. G., and Nevison, C. D.: Effects of sea ice cover on satellite-detected primary production in the Arctic Ocean, Biol. Letters, 12, 20160223, https://doi.org/10.1098/rsbl.2016.0223, 2016.

Kirk, J. T. O.: Light and Photosynthesis in the Aquatic Ecosystems, Cambridge Univ. Press, Cambridge, UK, 1983.

Kwok, R., Cunningham, G. F., Wensnahan, M., Rigor, I., Zwally, H. J., and Yi, D.: Thinning and volume loss of the Arctic Ocean sea ice cover: 2003-2008, J. Geophys. Res., 114, C07005, https://doi.org/10.1029/2009JC005312, 2009.

Lee, S. H. and Whitledge, T. E.: Primary and new production in the deep Canada Basin during summer 2002, Polar Biol., 28, 190197, 2005.

Lee, S. H., Whitledge, T. E., and Kang, S.: Recent carbon and nitrogen uptake rates of phytoplankton in Bering Strait and the Chukchi Sea, Cont. Shelf Res., 27, 2231-2249, 2007.

Lee, S. H., Joo, H. M., Liu, Z., Chen, J., and He, J.: Phytoplankton productivity in newly opened waters of the Western Arctic Ocean, Deep-Sea Res. Pt. II, 81, 18-27, 2012.

Lee, S. H., Yun, M. S., Kim, B. K., Joo, H., Kang, S. J., Kang, C. K., and Whitledge, T. E.: Contribution of small phytoplankton to total primary production in the Chukchi Sea, Cont. Shelf Res., 68, 43-50, 2013.

Lee, S. H., Kim, B. K., Lim, Y. J., Joo, H., Kang, J. J., Lee, D., Park, J., Ha, S.-Y., and Lee, S. H.: Small phytoplankton contribution to the standing stocks and the total primary production in the Amundsen Sea, Biogeosciences, 14, 3705-3713, https://doi.org/10.5194/bg-14-3705-2017, 2017a.

Lee, S. H., Joo, H. T., Lee, J. H., Lee, J. H., Kang, J. J., Lee, H. W., Lee, D., and Kang, C. K.: Seasonal carbon uptake rates of phytoplankton in the northern East/Japan Sea, Deep-Sea Res. Pt. II, 143, 45-53, https://doi.org/10.1016/j.dsr2.2017.04.009, 2017b.

Legendre, L., Ackley, S. F., Dieckmann, G. S., Gulliksen, B., Horner, R., Hoshiai, T., Melnikov, I. A., Reeburgh, W. S., Spindler, M., and Sullivan, C. W.: Ecology of sea ice biota, Polar Biol., 12, 429-444, 1992.

Levi, B. G.: The decreasing Arctic ice cover, Phys. Today, 53, 1920, https://doi.org/10.1063/1.882931, 2000.

Li, J., Glibert, P. M., and Alexander, J. A.: Effects of ambient DIN : DIP ratio on the nitrogen uptake of harmful dinoflagellate Prorocentrum minimum and Prorocentrum donghaiense in turbidistat, Chin. J. Oceanol. Limn., 29, 746-761, 2011.

Li, W. K., McLaughlin, F. A., Lovejoy, C., and Carmack, E. C.: Smallest algae thrive as the Arctic Ocean freshens, Science, 326, 539, https://doi.org/10.1126/science.1179798, 2009.

Martin, J., Tremblay, J. É., Gagnon, J., Tremblay, G., Lapoussière, A., Jose, C., Poulin, M., Gosselin, M., Gratton, Y., and Michel, C.: Prevalence, structure and properties of subsurface chlorophyll maxima in Canadian Arctic waters, Mar. Ecol.-Progr. Ser., 412, 69-84, 2010.

Maslowski, W., Marble, D., Walczowski, W., Schauer, U., Clement, J. L., and Semtner, A. J.: On climatological mass, heat, and salt transports through the Barents Sea and Fram Strait from a panArctic coupled ice-ocean model simulation, J. Geophys. Res.Oceans, 109, C03032, https://doi.org/10.1029/2001JC001039, 2004.

McCarthy, J. J., Garside, C., and Nevins, J. L.: Nitrogen dynamics during the Arabian Sea northeast monsoon, Deep-Sea Res. Pt. II, 46, 1623-1664, 1999.

McLaughlin, F. A., Carmack, E. C., Jackson, J. M., Ingram, R. G., and Allen, S. E.: Identification, characterization, and change of the near-surface temperature maximum in the Canada Basin, 1993-2008, Doctoral dissertation, University of British Columbia, 2010.

Niebauer, H. J., Alexander, V., and Henrichs, S.: Physical and biological oceanographic interaction in the spring bloom at the Bering Sea marginal ice edge zone, J. Geophys. Res.-Oceans, 95, 22229-22241, 1990.

Overland, J. E. and Wang, M.: When will the summer Arctic be nearly sea ice free?, Geophys. Res. Lett., 40, 2097-2101, 2013.

Pabi, S., van Dijken, G., and Arrigo, K. R.: Primary production in the Arctic Ocean, 1998-2006, J. Geophys. Res., 113, C08005, https://doi.org/10.1029/2007JC004578, 2008.

Parkinson, C. L., Cavalieri, D. J., Gloersen, P., Zwally, J. H., and Comiso, J. C.: Arctic sea ice extents, areas, and trends, 19781996, J. Geophys. Res., 104, 20837-20856, 1999.

Peterson, B. J., Holmes, R. M., McClelland, J. W., Vörösmarty, C. J., Lammers, R. B., Shiklomanov, A. I., Shiklomanov, I. A., and Rahmstorf, S.: Increasing river discharge to the Arctic Ocean, Science, 298, 2171-2173, 2002.

Platt, T., Harrison, W. G., Irwin, B., Horne, E. P., and Gallegos, C. L.: Photosynthesis and photo adaptation of marine phytoplankton in the Arctic, Deep-Sea Res. Pt. I, 29, 1159-1170, 1982.

Quadfasel, D.: Oceanography: The Atlantic heat conveyor slows, Nature, 438, 565-566, 2005.

Rachold, V., Grigoriev, M. N., Are, F. E., Solomon, S., Reimnitz, E., Kassens, H., and Antonow, M.: Coastal erosion vs. riverine sediment discharge in the Arctic shelf seas, Int. J. Earth. Sci., 89, 450-460, 2000.

Redfield, A. C.: The influence of organisms on the composition of seawater, The Sea, 2, 26-77, 1963.

Sakshaug, E.: Primary and Secondary Production in the Arctic Seas, in: The Organic Carbon Cycle in the Arctic Ocean, edited by: Stein, R. and MacDonald, R. W., Springer, Berlin, Heidelberg, 2004.

Sakshaug, E. and Holm-Hansen, O.: Factors governing pelagic production in polar oceans, in: Marine phytoplankton and productivity, 1-18, Springer, Berlin, Heidelberg, 1984.

Semiletov, I., Dudarev, O., Luchin, V., Charkin, A., Shin, K. H., and Tanaka, N.: The East Siberian Sea as a transition zone between Pacific-derived waters and Arctic shelf waters, Geophys. Res. Lett., 32, L10614, https://doi.org/10.1029/2005GL022490, 2005.

Shiklomanov, I. A., Shiklomanov, A. I., Lammers, R. B., Peterson, B. J., and Vorosmarty, C. J.: The dynamics of river water inflow to the Arctic Ocean, in: The freshwater budget of the Arctic Ocean (281-296), Springer, Dordrecht, 2000.

Shuter, B. G.: Size dependence of phophorus and nitrogen subsistence quotas in unicellular microrganisms, Limnol. Oceanogr., 23, 1248-1255, 1978. 
Slagstad, D., Ellingsen, I. H., and Wassmann, P.: Evaluating primary and secondary production in an Arctic Ocean void of summer sea ice: an experimental simulation approach, Prog. Oceanogr., 90, 117-131, 2011.

Slawyk, G., Collos, Y., and Auclair, J. C.: The use of the ${ }^{13} \mathrm{C}$ and ${ }^{15} \mathrm{~N}$ isotopes for the simultaneous measurement of carbon and nitrogen turnover rates in marine phytoplankton, Limnol. Oceanogr., 22, 925-932, 1977.

Son, S. H., Campbell, J., Dowell, M., Yoo, S., and Noh, J.: Primary production in the Yellow Sea determined by ocean color remote sensing, Mar. Ecol.-Prog. Ser., 303, 91-103, 2005.

Steinacher, M., Joos, F., Frölicher, T. L., Bopp, L., Cadule, P., Cocco, V., Doney, S. C., Gehlen, M., Lindsay, K., Moore, J. K., Schneider, B., and Segschneider, J.: Projected 21st century decrease in marine productivity: a multi-model analysis, Biogeosciences, 7, 979-1005, https://doi.org/10.5194/bg-7-979-2010, 2010.

Stroeve, J., Holland, M. M., Meier, W., Stroeve, J, Holland, M. M., Meier, W., Scambos, T., and Serreze, M.: Arctic sea ice decline: faster than forecast, Geophys. Res. Lett., 34, L09501, https://doi.org/10.1029/2007GL029703, 2008.

Subba Rao, D. V. and Platt, T.: Primary production of Arctic waters, Polar Biol., 3, 191-210, 1984.

Talling, J. F.: The phytoplankton population as a compound photosynthetic system, New Phytol., 56, 133-149, 1957.

Thomas, M. K., Kremer, C. T., Klausmeier, C. A., and Litchman, E.: A global pattern of thermal adaptation in marine phytoplankton, Science, 338, 1085-1088, 2012.

Tremblay, J. E. and Gagnon, G.: The effects of irradiance and nutrient supply on the productivity of Arctic waters: a perspective on climate change, in: Influence of climate change on the changing Arctic and sub-Arctic conditions. Proceedings of the NATO advanced research workshop, edited by: Nihoul, J. C. J. and Kostianoy, A. G., Liège, May 2008, Springer, Dordrecht, 73-94, 2009.

Tremblay, J. É., Legendre, L., Klein, B., and Therriault, C.: Sizedifferential uptake of nitrogen and carbon in a marginal sea (Gulf of St. Lawrance, Canada): Significance of diel periodicity and urea uptake, Deep-Sea Res. Pt. II, 47, 489-518, 2000.
Tremblay, J. É., Gratton, Y., Carmack, E. C., Payne, C. D., and Price, N. M.: Impact of the large-scale Arctic circulation and the North Water Polynya on nutrient inventories in Baffin Bay, J. Geophys. Res.-Oceans, 107, 26-31, 2002.

Vancoppenolle, M., Meiners, K. M., Michel, C., Bopp, L., Brabant, F., Carnat, G., Delille, B., Lannuzel, D., Madec, G., Moreau, S., and Tison, J. L.: Role of sea ice in global biogeochemical cycles: emerging views and challenges, Quaternary Sci. Rev., 79, 207230, 2013.

Vavrus, S. J., Holland, M. M., Jahn, A., Bailey, D. A., and Blazey, B. A.: Twenty-first-century Arctic climate change in CCSM4, J Climate, 25, 2696-2710, 2012.

Vedernikov, V. I., Demidov, A. B., and Sudbin, A. I.: Primary production and chlorophyll in the Kara Sea in September 1993, Okeanologiya, 34, 693-703, 1994.

Walsh, J. J.: Arctic carbon sinks: present and future, Global. Biogeochem. Cy., 3, 393-411, https://doi.org/10.1029/GB003i004p00393, 1989.

Wassmann, P., Duarte, C. M., Agusti, S., and Sejr, M. K.: Footprints of climate change in the Arctic marine ecosystem, Glob. Change Biol., 17, 1235-1249, 2011.

Whitledge, T. E., Malloy, S. C., Patton, C. J., and Wirick, C. D.: Automated nutrient analyses in seawater (No. BNL-51398), Brookhaven National Lab., Upton, NY, USA, 1981.

Yun, M. S., Chung, K. H., Zimmermann, S., Zhao, J., Joo, H. M., and Lee, S. H.: Phytoplankton productivity and its response to higher light levels in the Canada Basin, Polar Biol., 35, 257-268, 2012.

Yun, M. S., Kim, B. K., Joo, H. T., Yang, E. J., Nishino, S., Chung, K. H., Kang, S., and Lee, S. H.: Regional productivity of phytoplankton in the Western Arctic Ocean during summer in 2010, Deep-Sea Res. Pt. II, 120, 61-71, 2015. 